\title{
Customer perspective of Trans Metro Pekanbaru service on corridor Pandau- Ramayana
}

\author{
Muchammad Zaenal Muttaqin ${ }^{1, *}$, and $A b d u l$ Kudus Zaini ${ }^{1}$ \\ ${ }^{1}$ Islamic University of Riau, Civil Engineering Department, Pekanbaru, Indonesia
}

\begin{abstract}
Characteristic of public transport service in a city could be different one and another because of passenger itself. Passengers with their experience explained more about service from bus. This research has aim to know service performance from Trans Metro Pekanbaru (TMP) based from customer perspective. Factor Analysis and Gap analysis used to know dominating parameter that represent it. The result showed students and employees $(77.96 \%$ ) dominated for passenger group using Trans Metro Pekanbaru. All of customer perception could divide by three group among other psychological factor, primary needs service, and transit place factor. Psychological factor became highest opportunity to represent positive value of Trans Metro performance with level of service reach until $97.23 \%$ compared by its expectation. On the other side, transit place factor was only has $81.5 \%$ performance, thus it became primary focus for TMP to improve their performance to better service quality in the future.
\end{abstract}

\section{Introduction}

Transport can be defined as means to move people or goods from one place to another place. In general, there are two groups in transport, they are private transport and public transport. Public transport was differ than private transport. Public transportation is advanced transport organization that operate accessible transport that for all citizen or apart for them based on its rules or given policy [1]. It has function to help others to reach their destination place and reduce all problem from transport sector. Nowadays, many cities in the world has been developed public transport as backbone of system transportation in their cities. One of them is Pekanbaru in Indonesia.

Pekanbaru, as a developing city in Indonesia and has its target become one of metropolitan city in Indonesia has a problem with development of public transport system. Public transit system by bus in Pekanbaru handled for all component, whether for main route, bus station and transit routes. Satisfaction in the public transit system can affect people to go by this transport modes with continuously. The problem occur that people still not want to use Trans Metro. Trans Metro user is not yet reached their target. In fact, passengers of Trans Metro just only amount for about 4000 passengers per day, still far from the target 18000-20000 passengers per day. Effect from public transport problem in

* Corresponding author: muchzaenalmuttaqin@eng.uir.ac.id 
Pekanbaru could be shown with congestion in the road. Congestion in Pekanbaru always happened, especially on working hours [2]. In details, road capacity in Pekanbaru increasing by year with Level of Service $0.75-1.00$ which shown that already saturated and make congestion especially in the primary road in Pekanbaru [3]. Related with them, objective of this study contains discover how service characteristic from Trans Metro based from customer view. Furthermore, this study could be a foundation that what aspect that Trans Metro need to improve about its quality when serve customer.

\subsection{Literature review}

Service has different characteristic with product. Identification of services could be shown with its intangibility. Service cannot be shown because real product of service is an effort, moral, experience, process, performance or anything that people do to their target which is customer [4]. This thing make difficult to customer to evaluate service before they make decision before they use that service. Characteristic of the service may different one and another. It was related with how service can deliver its value to the customer. So that, knowing more about service characteristic took from customer as its object.

Public transport as apart of service has same characteristic with other service. It focused to meet customer needs with perceived value for customer as primary objective of the service. Identification of the services was the first evaluation how service can meet about people needs [4]. It would describe how service is created to serve customer in their activities.

Characteristic of the service was related with service marketing. Service marketing has concept based from what service offered and what customer perceived from them. Identification is a starting point before companies offer their service to customer. This process is needed to determine what right service that would be offered as same as customer needs. Identification is most effective method to know customer needs before services would be delivered for customer [5].

Customer has experience as the result of after services from the company. Experience would identify what the services has been perceived by customer. Customer experience has relationship between company and customer. Service characteristics dominated by customer experience [6]. It would affect evaluation process for the service. Service evaluation obtained during same time about production and consumption also after purchasing process. So that, customer experience would identify what characteristic of the service based from customer satisfaction about it.

Customer experience for the service showed by their perception about the service. Perception from customer determine how performance from its service works for customer. Performance could be one important aspect to evaluate about public transit operator, not just about profitability [7]. Performance itself make effect with satisfaction from customer and identify how service delivery went to customer that create service characteristic.

Service performance can be valued with customer perspective. Customer perspective played role for both company and customer by their experiences [8]. For company side, customer perspective built value and realize them to evaluate and increase progress for their quality. On the customer side, customer perspective would make perception for the products or services also expectation of the services. Comparison between both of them would affect customer loyalty with the company's products or services, see fig. 1 below. 


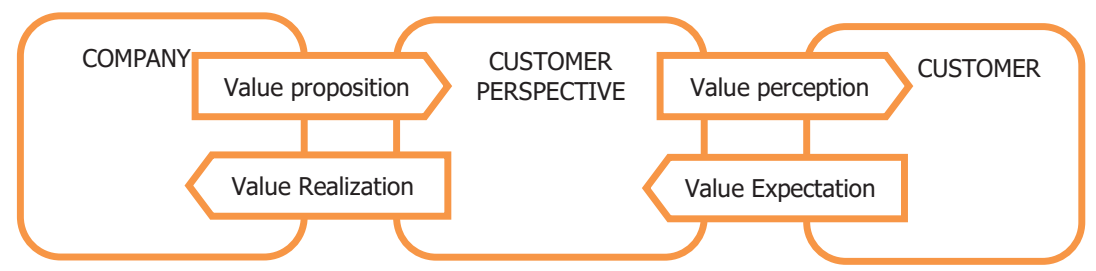

Fig. 1. Customer perspective on customer and company side

Customer perspective captured by perception from customer. Perception as one of component in experience play its role to make satisfaction and construct them to service quality. Perception was a cognitive process to know about information from its activity then give impression as unique thing from its information based on current condition [9]. Perception of service was obtained by comparing customer expectation with performance from the service. Performance of the service based on customer perspective would become a standard to know about how customer valued the service and what primary characteristic from the service that should be focused to make better quality service in the future.

\section{Methodology}

This study would be analyzed by quantitative approach. Quantitative approach emphasize to measure and analyze data with statistical, mathematical or numerical view and report them as generalization of the subject and explain what happened related with particular theme. Quantitative will give insight for conclusion that started from general view and end with specific as main purpose [10]. In details, this study used multivariate analysis with Exploratory Factorial Analysis and Servqual with gap analysis. Exploratory Factorial Analysis (EFA) used to collect and simplify data parameter that measured in this study. The result from this method was knowing about which parameter that dominated in TMP service especially on corridor Pandau-Ramayana. Finally, it would be know how characteristic of Trans Metro Pekanbaru (TMP) services based from customer perspective. On the other side, Servqual based from gap analysis would be used to know how fulfillment needs for customer expectation from TMP services.

Evaluate service based from passenger view. In the service process, there are two main component which consist of expected service and perceived service. In the service quality (Servqual) analysis, comparison between expected service and perceived service has known as "gap" analysis. Perceived service is what real services that given by company to the customer and expected service is what customer wants based on the service. Both of them would be evaluated and make perceived service quality which shown how service performance can fulfil customer wants [5]. Formula for gap analysis has given below,

$$
S Q=P-I
$$

where,

$S Q \quad=$ Service Quality,

$P=$ Perception,

$I=$ Importance.

This study collected data from questionnaire form that filled by passengers of TMP especially in corridor Pandau-Ramayana. Data has been collected by random sampling 
method on April and May 2017. Surveyor took questionnaire data from respondents who exist in the transit place when was waiting the bus and in the bus when the bus was running. Questionnaire divided by three section. First section was about data identification from passenger, second section was about passenger perception actually about TMP service and last section about what passenger expectation for TMP service.

\section{Discussion}

\subsection{Profile of TMP corridor Pandau-Ramayana}

Trans Metro Pekanbaru was a public transport in Pekanbaru which adopted from mass transportation systems in the other cities before in Indonesia, like in Jakarta with Trans Jakarta and Yogyakarta with Trans Jogja. Trans Metro Pekanbaru has operated first in 2009 based from Transportation Ministry's policy and operated just only two routes [4]. In 2012, Trans Metro Pekanbaru develop their routes become 7 routes and going to develop more based on demand and accessibility in Pekanbaru city. Corridor Pandau-Ramayana became first route that operated by Trans Metro Pekanbaru (TMP). This corridor started from Pandau Housing (border area between Pekanbaru and Kampar) and Ramayana (Business Central District of Pekanbaru), see figure 2 below,

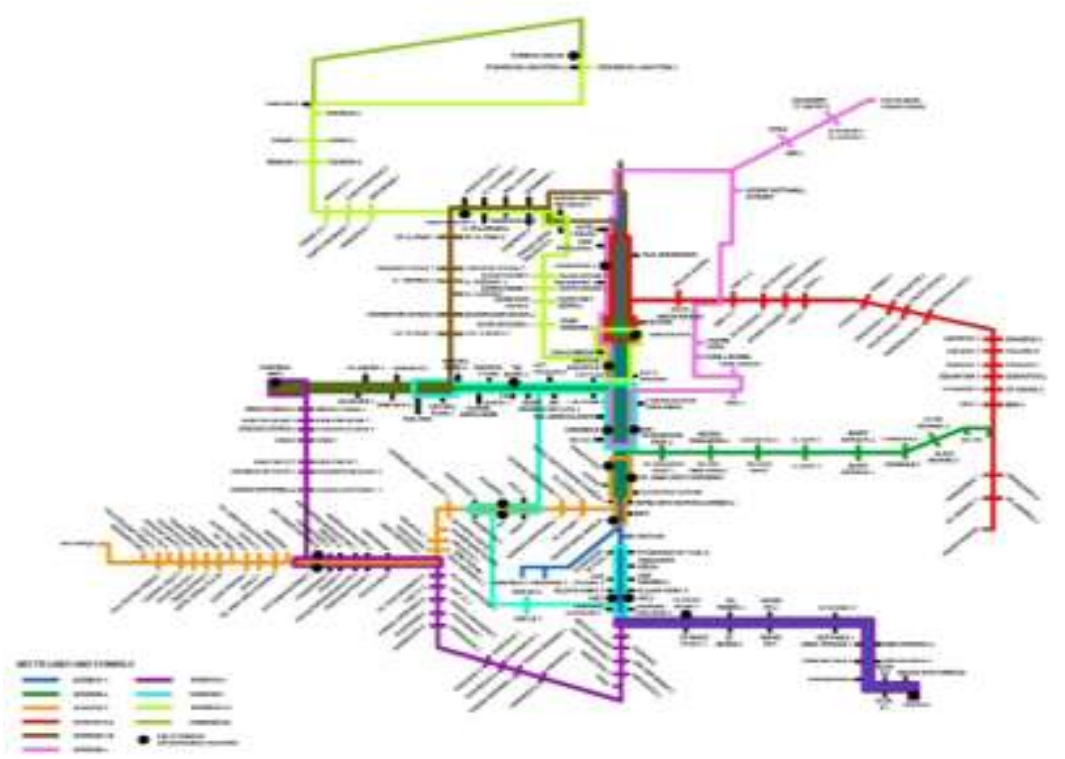

Fig. 2. Trans Metro Pekanbaru routes

This corridor is one of primary routes in TMP routes, because this passed national road in Pekanbaru and passed many office, public place, education place until government office. Thus, the corridor attracted passenger by its location and in fact, this corridor is the largest amount of passengers in TMP than other routes [11]. The bus for corridor PandauRamayana has capacity 83 people and scheduled from 06.00 in the morning until 21.00 in the night (15 hours) everyday. Trans Metro Pekanbaru operated by Public transit consortium company and controlled by Transportation Ministry of Pekanbaru city [12]. 


\section{Data and analysis}

\subsection{General description}

This study used data from questionnaire with 249 sample from 300 sample has been distributed. Based from sample, domination of students and employee has been shown as passengers of TMP corridor Pandau-Ramayana. 40.56\% passengers had profession as students and $37.4 \%$ passengers was employees. Another passengers was entrepreneur (11.2 $\%)$ and others, like unemployment etc $(14.5 \%)$. Other description showed that distance for transit place was about $100-500$ meters. Many passengers used Trans Metro Pekanbaru where it had distance about $100-500$ meter $(51 \%)$ from their destination. Another result, $37.3 \%$ passengers had distance from transit place of Trans Metro less than 100 meters. This result means that passenger had tendency to use Trans Metro where accessed about 500 meters, On the other word, attraction from passenger to use Trans Metro valued high when it accessed $100-500$ meters.

Motives from passengers analyzed to know stimulant factor from passengers before using Trans Metro Pekanbaru. Figure 3 showed that there was no domination factor that attract customer to use Trans Metro Pekanbaru. Pricing factor become highest motives why passenger want to use Trans Metro (13 \%). Nowadays, passengers must pay 4000 Indonesian Rupiah for each trip using Trans Metro or 1000 Indonesian Rupiah if passenger is student below Junior High School. Another motives showed about safer, environmental friendly, reliable and safer was second highest motives about reason from passengers why using Trans Metro Pekanbaru (12\%). It means about psychological factor attracted passenger to use Trans Metro as their modes. As one of modes choice factor, psychological and past behavior can highly affected for decision making process in the future [13].

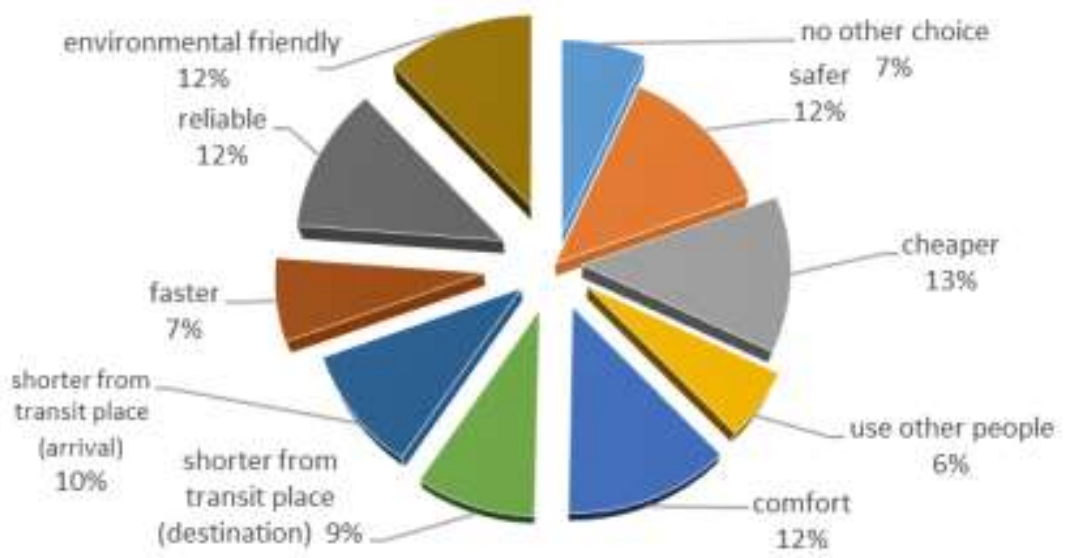

Fig 3. Motives from passenger to use Trans Metro Pekanbaru

As explained above, factorial analysis used to make advance exploration about quality service of Trans Metro Pekanbaru. In this case, parameter of perception would be grouped and defined with identical relationship between variables. Service performance captured by customer's impression when used Trans Metro Pekanbaru. Dominating parameter would be known as highest tendency how service worked for passenger. The result showed that parameter of perception could divide by three groups based on factorial analysis. There are psychological factor, primary needs services, and transit place factor (see appendix a). Psychological factor has included responsiveness, and assurance of the service. 
Responsiveness and assurance were apart from dimension of service quality [14]. Responsiveness on this group contained faster services, employees are nice and friendly, employees were always ready to serve customer and good caring for passenger. Assurance on this group contained cleanliness in the bus, clear information from employee, good looking from employee. Finally, all of parameter in this group make positive value and improve psychological value for passenger when using Trans Metro Pekanbaru. Second group was primary needs service. This group contain more about what primary service that Trans Metro did to their passengers. Parameter that included in this group were about safety in the bus, sitting place facility, easy to get ticket, accessibility, punctuality etc (see appendix a). Passenger had high expectation that this parameter should be served first to them first. On the standard rules, like SK Dirjen no.687 tahun 2002, this parameter was primary parameter to evaluate public transport, especially for bus.Last group in this case was transit place factor. This group contained more about transit place condition that affect passenger to use Trans Metro Pekanbaru, like waiting time, safety, comfortability and cleanliness in the transit place.

Based from gap analysis, all parameters had negative value on gap value. It means Trans Metro Pekanbaru still unable to make positive satisfaction to passengers. Thus, it need more improvement from Trans Metro Pekanbaru about service quality. The higher service quality would make higher satisfaction from customer about the services, vice versa [5]. In this case, Trans Metro Pekanbaru need to see advance what proper improvement that can improve service quality to make positive value in gap analysis (performance is more than expectation).

Table 1. Customer perspective of Trans Metro Pekanbaru

\begin{tabular}{|c|c|c|c|c|c|}
\hline \multirow{2}{*}{ Factors } & \multirow{2}{*}{ Parameter } & \multicolumn{4}{|c|}{ Component } \\
\hline & & Performance & Importance & Fulfillment level & Gap \\
\hline \multirow{10}{*}{$\begin{array}{l}\text { Psychological } \\
\text { factor }\end{array}$} & Faster and responsive services & 7.87 & 7.92 & $99.39 \%$ & -0.05 \\
\hline & Good looking from employees & 8.03 & 8.13 & $98.76 \%$ & -0.10 \\
\hline & Comfortability & 8.14 & 8.29 & $98.21 \%$ & -0.15 \\
\hline & Employees are ready to serve customer everytime & 7.98 & 8.14 & $98.03 \%$ & -0.16 \\
\hline & Employees are nice, friendly and polite & 8.05 & 8.28 & $97.23 \%$ & -0.23 \\
\hline & Cleanliness In the bus & 8.13 & 8.43 & $96.52 \%$ & -0.29 \\
\hline & Good caring for passenger & 7.76 & 8.04 & $96.46 \%$ & -0.29 \\
\hline & Clear information from employees & 8.00 & 8.31 & $96.23 \%$ & -0.31 \\
\hline & Driver driving attitude & 7.95 & 8.27 & $96.07 \%$ & -0.33 \\
\hline & The bus already modern bus & 7.87 & 8.24 & $95.51 \%$ & -0.37 \\
\hline \multirow{8}{*}{$\begin{array}{c}\text { Primary needs } \\
\text { service }\end{array}$} & Safety in the bus & 8.00 & 8.20 & $97.55 \%$ & -0.20 \\
\hline & Sitting place facility & 7.87 & 8.10 & $97.17 \%$ & -0.23 \\
\hline & Easy to get ticket & 7.82 & 8.16 & $95.86 \%$ & -0.34 \\
\hline & Accessibility & 7.46 & 7.80 & $95.72 \%$ & -0.33 \\
\hline & Facility in the bus & 7.78 & 8.14 & $95.56 \%$ & -0.36 \\
\hline & Operating time & 7.41 & 7.88 & $93.99 \%$ & -0.47 \\
\hline & Clearly information in the transit place & 7.27 & 7.73 & $93.98 \%$ & -0.47 \\
\hline & Punctuality & 7.19 & 7.74 & $92.89 \%$ & -0.55 \\
\hline \multirow{4}{*}{$\begin{array}{l}\text { Transit place } \\
\text { factor }\end{array}$} & Waiting time & 6.47 & 7.57 & $85.37 \%$ & -1.11 \\
\hline & Safety in the transit place & 6.21 & 7.41 & $83.75 \%$ & -1.20 \\
\hline & Comfortability in the transit place & 5.93 & 7.47 & $79.31 \%$ & -1.55 \\
\hline & Cleanliness in the transit place & 5.88 & 7.58 & $77.58 \%$ & -1.70 \\
\hline
\end{tabular}

The number of group represent about how performance of Trans Metro compared with its expectation from passengers. The result showed that first group (psychological factor) has smallest gap, which means passengers valued that performance of Trans Metro Pekanbaru was in nearest value with their importance (see table 1 below). First group has 
level of service about $97.23 \%$ performance compared with its importance. Trans Metro Pekanbaru should be improved more in this parameter group and promote it to other society. It would attract more people to use Trans Metro Pekanbaru because of its performance value that nearest from its importance. Another result showed that Transit place factor has smallest level of service and highest negative value for gap value. It means that passengers valued that there were more problem exists for transit place factor on Trans Metro Pekanbaru services. Thus, performance of Trans Metro Pekanbaru still lower than passenger's importance. Smallest level of service was on cleanliness in the transit place with score about $77.58 \%$. Passengers valued there was not clean in the transit place so that make them disappointed for the service. Trans Metro Pekanbaru had more responsibility to solve the problem for better service quality especially in the transit place.

Table 2. Performance and importance of Trans Metro Pekanbaru

\begin{tabular}{|l|c|c|c|c|}
\hline \multirow{2}{*}{\multicolumn{1}{|c|}{ Factors }} & \multicolumn{4}{c|}{ Component } \\
\cline { 2 - 5 } & Performance & Importance & Level of Service & Gap \\
\hline Psychological factor & 7.98 & 8.20 & $97.23 \%$ & -0.23 \\
\hline Primary needs service & 7.60 & 7.97 & $95.37 \%$ & -0.37 \\
\hline Transit place factor & 6.12 & 7.51 & $81.50 \%$ & -1.39 \\
\hline
\end{tabular}

\section{Conclusions}

Capturing about customer perspective on public transport services was important to see how public transport can satisfy customer and affect its service performance. Performance of the service based on customer perspective would become a standard to know about how customer valued the service and what primary characteristic from the service that should be focused to make better quality service in the future. This study used service perception from passengers as a key to captured service performance of Trans Metro Pekanbaru. In this case, students and employees dominated on passenger type of Trans Metro Pekanbaru. Parameter for perception of Trans Metro Pekanbaru divided by three groups, that is psychological factor, primary needs service and transit place factor. Trans Metro Pekanbaru should be improve their performance from negative value for all parameter on gap analysis. Based from each group, psychological factor is highly dominated on this service and became highest positive value for passenger because of its smallest negative value on gap analysis (-0.23). Improving value for this parameter could be attracted other customer to use Trans Metro and pride for the service. On the other side, transit place factor became highest negative value (-1.39). It was urgent to improve this parameter, like comfortability in the transit place $(-1.5)$ and cleanliness in the transit place $(-1.7)$. Customer feels that transit place factor might be a reason to will not used Trans Metro again in the future. Finally, customer perspective was a key how service performance of public transport service and could be a comparison to evaluate its performance in addition using exist rules, like company standard, or another rules that applicable.

\section{References}

1. Aarts, H., Verplanken, B., \& Knippenberg, A. Predicting behaviour from actions in the past: Repeated decision making or a matter of habit?. Journal of Applied Social Psychology, 28(15), 1355-1374. (1998).

2. Dziekan, K. Ease-of-use in public transportation - A user perspective on information and orientation aspects. Unpublished doctoral thesis in traffic and transport planning, Infrastructure and Planning Royal Institute of Technology Stockholm, Sweden (2008). 
3. Panjaitan, A. M. Kajian Sistem Jaringan Jalan di Wilayah Kota Pekanbaru. Jurnal Teknik Sipil USU, 2(1) (2013).

4. Saputra, Parada Afkiki Eko. Evaluasi Kinerja Simpang Tiga Bersinyal Jalan Sudirman-Jalan Tuanku Tambusai Pekanbaru.S1 Thesis. Atma Jaya University, Yogyakarta. (2011).

5. Muttaqin, M. Z Promoting bus as alternative transport modes in the city based from customer view (case study : Trans Metro Pekanbaru for engineering students in islamic university of Riau, Indonesia). Master Thesis. Universitas Gadjah Mada. Yogyakarta . (2016).

6. Zeithaml, V. A., Parasuraman, A., \& Berry, L. L. Delivering quality service: Balancing customer perceptions and expectations. Simon and Schuster. (1990).

7. Berry, L. L., \& Parasuraman, A. Marketing service. Competing through Quality, New York. (1991).

8. Joewono, T. B., \& Kubota, H User satisfaction with paratransit in competition with motorization in indonesia: anticipation of future implications.Transportation, 34(3), 337-354. . (2007).

9. Gentile, C., Spiller, N., \& Noci, G. How to sustain the customer experience:: An overview of experience components that co-create value with the customer. European Management Journal, 25(5), 395-410. (2007).

10. Gentile, C., Spiller, N., \& Noci, G. How to sustain the customer experience:: An overview of experience components that co-create value with the customer. European Management Journal, 25(5), 395-410. (2007).

11. Sultana, S., \& Rana, S. Service Quality:(Service Gap Analysis) A case study-" Komvux". Master Thesis in Business Administration.Master International Management of Gotland University. (2010).

12. Department of Transportation. Data Jumlah penumpang Trans Metro Pekanbaru Tahun 2015. Bidang Angkutan Dinas Perhubungan Kota Pekanbaru. (2015).

13. Hafis, A., Imam, R., Hakim, A., \& Santoso Haryono, B. Aktor Pelaksana Pengelolaan Transportasi Publik Perkotaan (Studi Kasus Bus Trans Metro Di Kota Pekanbaru). WACANA, Jurnal Sosial dan Humaniora, 16(4), 171-178. (2014).

14. Aarts, H., Verplanken, B., \& Knippenberg, A. Predicting behaviour from actions in the past: Repeated decision making or a matter of habit?. Journal of Applied Social Psychology, 28(15), 1355-1374. (1998).

15. Parasuraman, A, Zeithaml, V. A. and Berry, L. L. SERVQUAL: A multiple-item scale for measuring customer perceptions of service quality. Journal of Retailing. Vol. 64, No. 1. (1998). 